\title{
Structure of a year cycle of athletes training in aerobics (woman) with various psychophysiological and functional features
}

Shepelenko T.V. ${ }^{1 \mathrm{ABCDE}}$, Kozina Zh.L. ${ }^{2,3 \mathrm{ABCDE}}$, Cieślicka M. ${ }^{4 \mathrm{ABC}}$, Prusik K. ${ }^{5 \mathrm{CDE}}$, Muszkieta R. ${ }^{6 \mathrm{AB}}$, Osiptsov A.V. ${ }^{7 \mathrm{ADE}}$, Kostiukevych V.M. ${ }^{8 \mathrm{AB}}$, Bazilyuk T.A. ${ }^{9 \mathrm{ABC}}$, Sobko I.N. ${ }^{10 \mathrm{CDE}}$, Ryepko O.A. ${ }^{2 \mathrm{ABC}}$, Polishchuk S.B. ${ }^{2 \mathrm{ABC}}$, Ilnickaya A.S. ${ }^{2 \mathrm{DE}}$

${ }^{1}$ Ukrainian State University of Railway Transport, Ukraine

${ }^{2}$ H.S. Skovoroda Kharkiv National Pedagogical University, Ukraine

${ }^{3}$ Belgorod National Research University, Russia

${ }^{4}$ Kazimierz Wielki University in Bydgoszcz, Poland

${ }^{5}$ Department of Tourism and Recreation, Gdansk University of Physical Education and Sport, Poland

${ }^{6}$ Nicolaus Copernicus University in Torun, Poland

${ }^{7}$ Mariupol State University, Ukraine

${ }^{8}$ Mykhailo Kotsyubynskyi Vinnitsa State Pedagogical University, Ukraine

${ }^{9}$ Kiev National University of Technology and Design, Ukraine

${ }^{10}$ Kharkov National Economic University, Ukraine

Authors' Contribution: A - Study design; B - Data collection; C - Statistical analysis; D - Manuscript Preparation; E - Funds Collection.

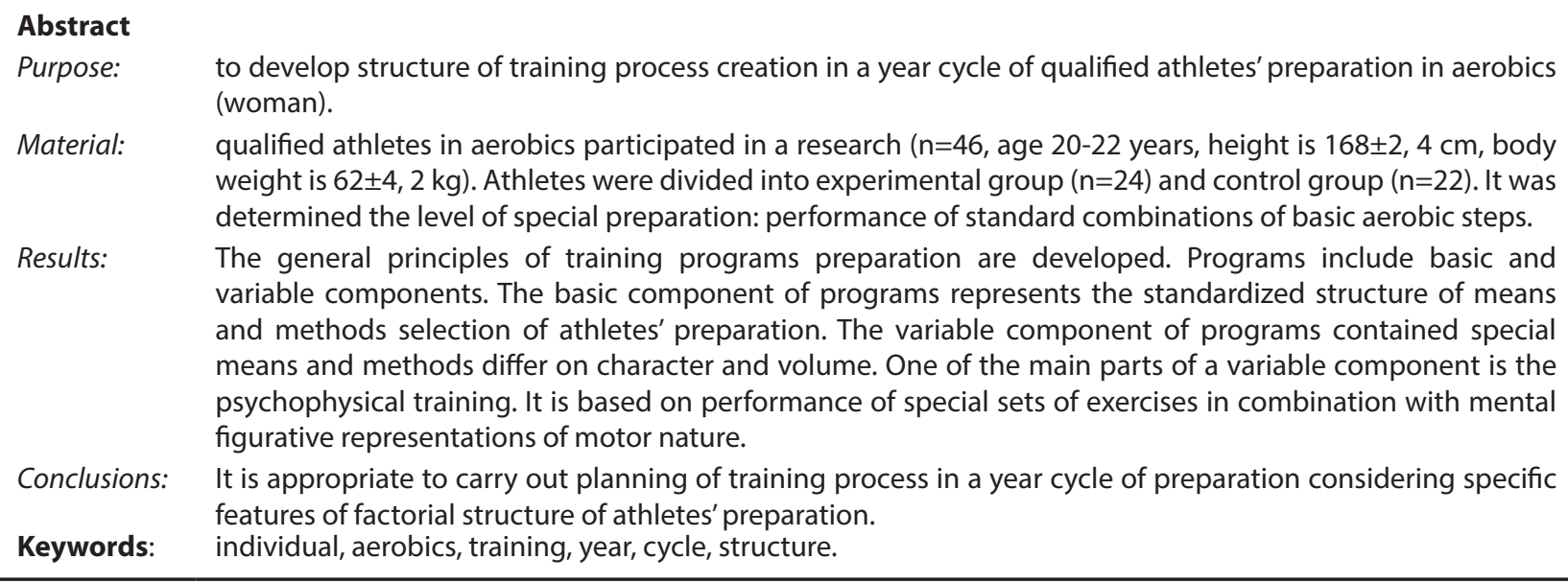

\section{Introduction}

Nowadays problem of training process creation in a year cycle of preparation is relevant for all kinds of sport. The sport aerobics is not an exception. However there is not enough current scientific research in sport aerobics concerning structure determination of athletes' training in a year training cycle. Andersyan K.B. [1] points that nowadays there are a lot of literatures devoted to problems of sport aerobics in adjacent kinds of sport: sport and art gymnastics, sport acrobatics, figure skating, synchronized swimming. The features of training process creation are different in each kind of sport. The sport aerobics is independent type of gymnastics which have specific system of exercises, training and refereeing.

Andersyan K.B. [1] defined quantity and variety of elements in combinations corresponding to the program qualified athletes. The author designated tendencies of compositions' development. Correlations between required and factual structural groups of elements in combinations are also defined. The author developed model of a year cycle for qualified athletes' preparation

\footnotetext{
@ Shepelenko T.V., Kozina Zh.L., Cieślicka M., Prusik K.,

Muszkieta R., Osiptsov A.V., Kostiukevych V.M., Bazilyuk T.A.,

Sobko I.N., Ryepko O.A., Polishchuk S.B., Inickaya A.S., 2018

doi:10.15561/18189172.2018.0105
}

in sport aerobics. The model consists of two semi-annual cycles. Each model has the following mesocycles: «involving», «with emphasis on strength», «with emphasis on technique», «stabilized»; precompetitive, competitive and transitional. Five typical microcycles are developed on the basis of distribution and concentration of various training means.

However record of athletes' specific features during training process creation in a year cycle of preparation was not previously carried out.

Most of authors in aerobics researches note its healthimproving effect, influence on functional systems of organism, its esthetic and art role. Li Y. [2] revealed influence of dancing aerobics on a functional condition of women's college students. The author showed that application of dancing aerobics influences positively on cardiopneumatic function and aerobic metabolic cellular activity.

Other authors $[3,4]$ showed expediency of change in content of physical training in colleges and universities towards increase in number of aerobics classes. Similar results are received in other researches $[5,6]$. Authors showed advantage of aerobics application at schools, universities and colleges. 
The offer of Zhou M.H et al. [7] attracts interest to application of «fighting aerobics» at primary and high school. According to authors' opinion, «fighting aerobics» has to be based on traditional Chinese martial arts. Fighting aerobics give profound understanding to pupils in martial arts; strengthening their correct understanding of martial art; awakes interest and enthusiasm of students in martial arts; contributes to the further development of martial arts. Other research is devoted to importance of talent identification in athletes of martial arts [8].

Li A. [9] analyzes physiological and psychological features of qualified athletes in sports aerobics who were traumatized. The relevant rehabilitation activities are offered. The author offers structure of training process for rehabilitation after injuries. The author points that the reasons of sport injuries are difficult and multifaceted. The author analyzed the psychological reasons of sports injuries. It gives chance to facilitate effective rehabilitation of athletes.

Li L. [10] offered to use interactive technologies for increase in study efficiency in sport aerobics. The offered technologies improve development of motor visualization system. It allows to carry out interactive actions between teachers and pupils. The author offers a new method of computer system in sport training.

In other researches were established: Influence of audiovisual incentives on psychophysiological reactions during physical exercises [11]; Spontaneous effect of musical expression speed on quality of motor [12]; Impact of music and video on perceived tension during exercises of high intensity [13]; The modulating effects of listening music at classes [14]; Parameters of model for musical biological feedback [15]; Effect of preliminary music for sports activities or physical exercises [16].

$\mathrm{Wu}$ T. [17] offered dynamic hierarchical mode in training process and in creation of compositions in sport aerobics. Other researches show necessity of ensuring level of athletes' health: determination of correlation features of subjective and physiological parameters on reaction to load [18-20]; due to use of modern techniques of a cardio-strength training [21,22]; application of tests for evaluation of functionality [23-25]; application of biochemical tests for determination of health level [2628]; increase in indicators of life quality [29-31].

Thus, the problem of training process creation in a year cycle is not enough studied. In other researches [32] was offered the algorithm of teams forming in sport aerobics. It is based on specific features of athletes' preparation structure. Specific features of preparation structure could be defined by application of methods of multidimensional analysis.

The method of the multidimensional analysis is also used in other kinds of physical training and sport: for network analysis of competitive sports [33, 34]; forecasting of player's success [35] and forecast of the maximum HR at children and teenagers [36]; forecasting of injuries at athletes in track and field events [37], American soccer [38], snowboard [39].

It is logical to suppose that record of structure features of athletes' preparation in sport aerobics is a necessary element of training process planning. Such approach will allow to increase efficiency of athletes' training.

The purpose of the research is to develop structure of training process creation in a year cycle of qualified athletes' preparation in aerobics (woman).

\section{Material and methods}

Participants. Qualified athletes in aerobics participated in a research ( $\mathrm{n}=46$, age $20-22$ years, height is $168 \pm 2,4$ $\mathrm{cm}$, body weight is $62 \pm 4,2 \mathrm{~kg}$ ). Athletes were divided into experimental group $(\mathrm{n}=24)$ and control group $(\mathrm{n}=22)$.

Organization of a research: It was defined strength, high-speed strength, coordination opportunities and flexibility. Definition of strength opportunities was carried out according indicators of right and left hands dynamometry and according the time of keeping the right angle in hanging. Definition of high-speed abilities' development was carried out in long jump test on the spot by two legs push. $30 \mathrm{~m}$ run test was used for definition the speed development as a run with the maximum speed. Evaluation of flexibility was carried out according tests results: forward bend, forward split.

Evaluation of coordination abilities was carried out according to results of «Flamingo» test (evaluation ability to maintain balance): athlete tries to balance as long as possible (the second leg is pulled up to a buttock and is kept by a hand) on $50 \mathrm{~cm}$ long support (height $4 \mathrm{~cm}$, width $3 \mathrm{~cm})$.

Determination of level of special preparation was evaluated on the level of standard combinations' performance of basic aerobic steps. Evaluation was made on the basis of 10 points.

It was developed the general scheme of team and individual training of athletes. Similar schemes are used in competitive sports [40]. It looks like as follows.

The first direction provides creation of an algorithm of mathematical systematization and processing of a wide range of indicators reflecting the separate parties of preparation and athlete state. This direction considers state of player or group of players in separate time point. Determination of group (team) and individual structure of preparation of athletes is supposed in this direction. Then athletes divide into groups by means of cluster analysis.

The second direction is connected with the analysis of factors stipulated individual dynamics of athletes' game effectiveness. This direction supposes creation of regression models of competitive efficiency of athletes' dynamics. Application of these models is possible for the forecast of results. In our work this direction is reflected in individual approach to training process creation.

The third direction is connected with development of interactive technologies. It allows to reach qualitatively new level in various aspects of training process. In our research this direction is expressed in application of printing and video manuals for visual perception of various aspects in modern sport aerobics. In researches of Sobko I. [41] interactive technologies contain an integrated component of complex impact on consciousness and on 
motor development of athletes.

Team and individual programs of athletes' training are formed based on received results.

Psychological conditions of practical implementation of this system should be considered.

First of all athlete should take responsibility for own preparation. The athlete must realize that only person is responsible for own destiny in sport. It is necessary to notice that coacher must also take responsibility for athlete's training. It means profound understanding of task for the successful decision of preparation plan.

The second step and necessary condition is aiming at the best result. It means that the aiming at high sports result is necessary for every athlete. It means that athlete and coacher have to believe in such reality.

These two conditions promote formation of directed development of the self-organized system (athlete and team). It is provided a certain organization of preparation' process.

It is necessary to define the leading factors of athlete's preparation. It can be done by comparison of certain indicators of preparation. It is possible to define the leading direction of preparation by intuitive following that direction which is closer to athlete. It will cause development of leading factors and «improvement» of losing factors. Redistribution of emphases on «leading» and «losing» components must be individual for every athlete. Then cluster analysis was applied to division athletes into groups. This help to form teams for performances in various competitive categories.

Statistical analysis. Digital material was processed by means of traditional methods of mathematical statistics. It was determined arithmetic mean, mean square deviation (standard deviation) for each parameter. The obtained data processed with the help of programs Excel and SPSS. Deviations were considered reliable at significance point $\mathrm{p}<0,05$.

\section{Results.}

The scheme of training process' planning was developed. The scheme considered individual factorial structure of preparation. The system of means and methods of athletes' educational and training process creation consisted in the following provisions.

1. It was focused on development of the leading factors and their tendency to a certain style of motor activity during the development of individual programs preparation. It was defined groups of leading and losing factors for every athlete. Amount of factors more then $50 \%$ was denoted as leading factors. Other factors were denoted as losing. $60-80 \%$ of individual preparation was devoted to development of leading factors. $20-40 \%$ was devoted to development of losing factors. The emphasis on development the leading factors increased before the competitive period [40]. The correlation of development means of leading and losing factors was 70:30 in the competitive period.

In the process of team formation (pairs, trios, groups of five or eight athletes) we were based on the data of cluster analysis: degree of athletes-men and athleteswomen «similarity» and their division into groups. Cooperative groups were formed depending on training tasks and features of the specific program: of «similar» athletes; of different athletes.

2. Individual regularities of «increase» and «decrease» in physical well-being were considered in the process of creation the individual preparation programs. More complex exercises were offered to athletes during the periods of «increase» in physical well-being. Time of recovery increased and loads decreased during the periods of «decrease» in physical well-being. The relative volume of applied means aimed at the development of leading factors of individual preparation (up to $75-80 \%$ ) also increased. The developed interactive technologies were widely applied.

3. It was applied means of multimedia technologies, a psychophysical training, means of art and other ways of consciousness' activization. Features and tendencies of athletes were considered. Features of individual factorial structure of preparation and regularities of dynamics of functional state are also considered.

It was formulated the theoretical concept of individualization process of athletes' training in sport aerobics. The concept is based on the system analysis, regularity of self-organized systems development, Anokhin P.K theory of functional systems. [42]. The system of individualization provides application of such methods as: method of structure determination of athletes' preparation and identification of the leading factors in structure of preparation; method of teams formation by means of cluster analysis; method of creation of original preparation techniques with application of special techniques of psychophysical training and interactive technologies.

These directions stipulate appropriate means of integrated preparation. These means are based on features of preparation factorial structure and results of cluster analysis. It allows to find special way of preparation (fig. 1) for every athlete. We determined factors of individual structure of athletes' preparation. Indicators which correlate with them are also defined. Means of physical, technical, psychophysical, artistic and psychological training in individual and team programs of preparation are distributed. Approximate models of means' distribution in individual training of athletes are presented in table 1.

Process of athletes training contained a basic and variable component. The basic component made $70 \%$ of means in the general system of athletes' training. The variable component made $30 \%$ of means. In control groups standard team forms of training process creation were used. In experimental groups results of the cluster analysis of test results and appropriate programs of preparation were used. For athletes with prevailing development of certain factors were made approximate models of means' distribution of preparation types. The choice of means depended on periods of physical wellbeing dynamics. The percentage correlation of means depended on leading factor and the period of functional 


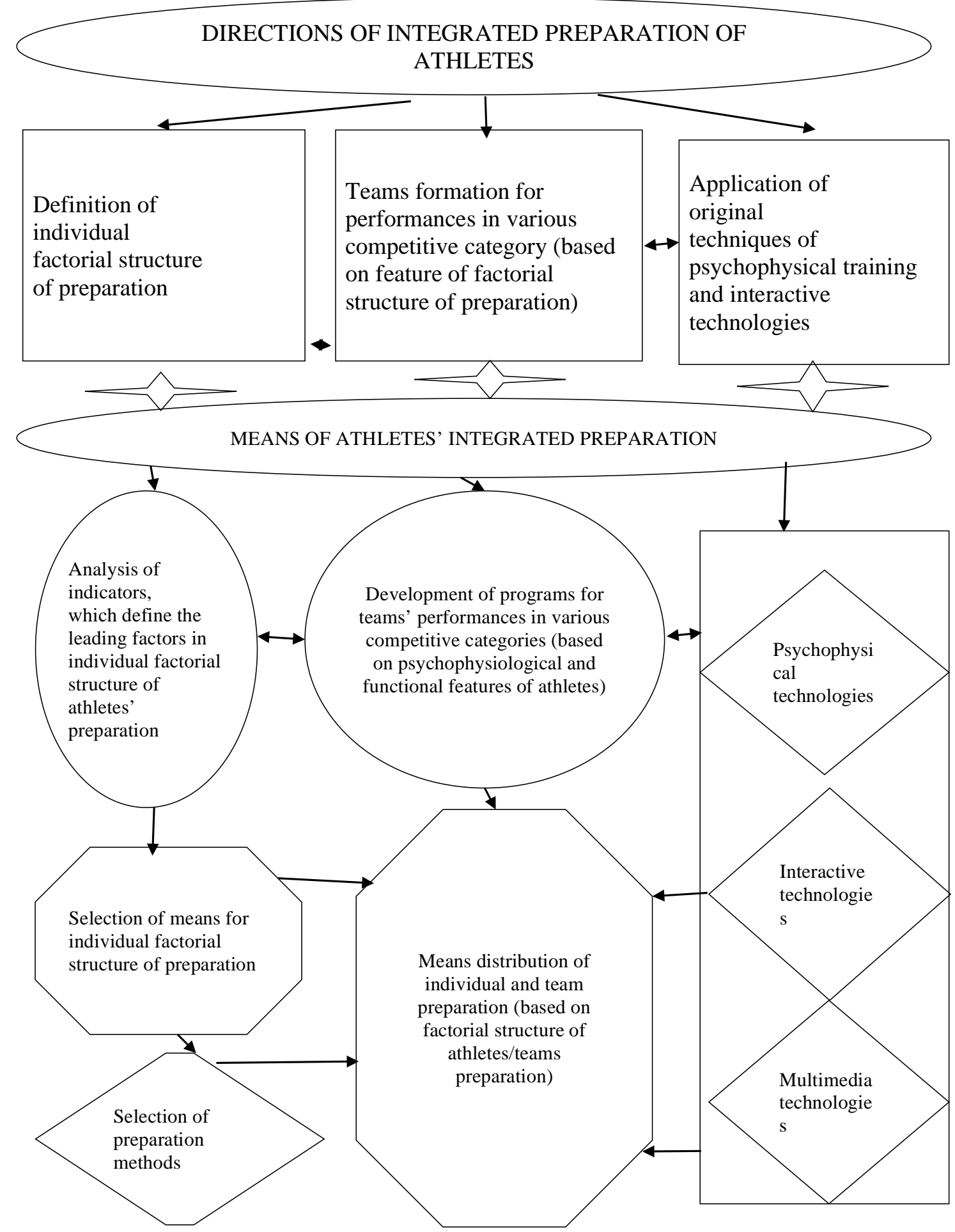

Fig. 1. Directions, methods and individualization means of athletes training

state of dynamics. In each microcycle $30 \%$ of time was devoted to group and individual training of athletes: athletes received individual tasks, groups were formed on the basis of the cluster analysis data. Approximate models of means' distribution in individual programs of athletes are presented in table 1.

Training process in an annual cycle was divided into three periods: preparatory $(15-30 \%)$; competitive (50-75\%); transitional (10-20\%). These three periods composed big cycle of training. Educational and training work in groups was divided into two big cycles: first - winter-spring (approximately October-March), second - spring-summer-autumn (approximately AprilSeptember).

In every period of educational and training process all types of preparation were carried out: physical, technical, group (individual), psychophysical, theoretical. The preparatory period began with each new cycle of 
Table 1. Means' distribution in individual programs of athletes' training (\%)

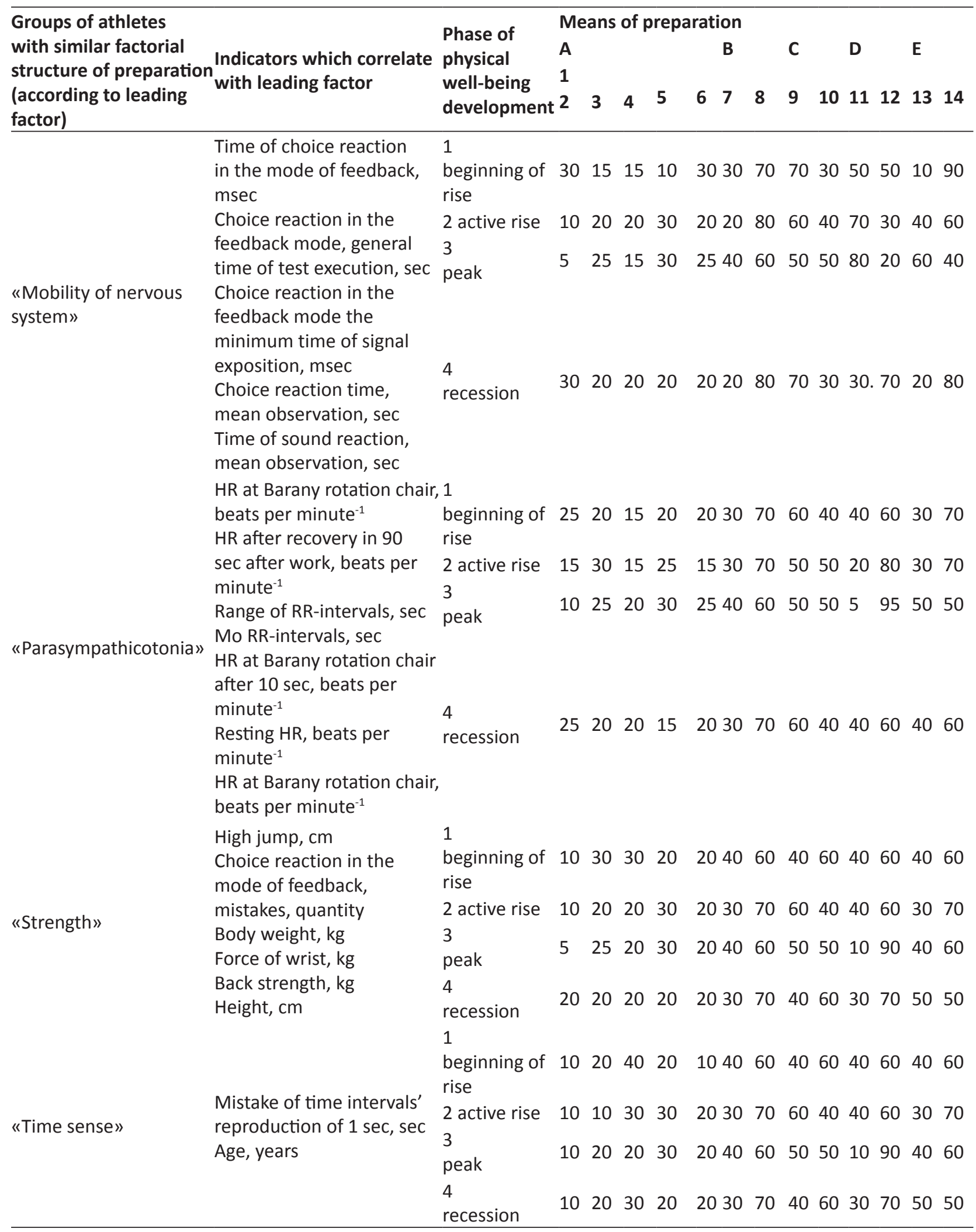

Note. HR - heart rate, A - Physical preparation, B - Technical preparation, C - Team (individual) preparation, D Theoretical preparation, E-Psychophysical preparation. 1-Development of general and special endurance, 2-Aerobic endurance, 3 - Anaerobic and glycolytic endurance, 4 - Anaerobic-creatine phosphate endurance, 5 - Development of high-speed and power qualities, 6 - Development of coordination, 7 - Training of basic elements, 8 -Training of «special» elements, 9 - Training of individual actions, 10 - Training of group interactions, 11 - Work on performances analysis of best world team, 12 - Work on analysis of pieces of music, 13 - With application of special sets of exercises of integrated influence, 14 - With application of art means and interactive technologies. 
educational and training process. This period finished before the start of main competitions.

At a stage of the general preparation a lot of attention was paid to development of physical qualities. $40-45 \%$ of the general time was devoted to physical training. Comparison of general and special physical training made a correlation $2: 1.35-40 \%$ of the general time was devoted to technical training. $20-25 \%$ of the general time was devoted to group preparation. Much attention at all stages was paid to psychophysical and theoretical preparation.

Stage of special preparation. $25-30 \%$ of the general time was devoted to development of functionality. The contribution of special physical training increased. $30-35 \%$ of the general time was devoted to technical training. $35-40 \%$ of the general time was devoted to team preparation.

Stage of precompetitive preparation. $20-25 \%$ of the general time was devoted to physical training. Special physical training dominated over the general physical training. Comparison of the general and special physical training makes 1: $2.30-35 \%$ of the general time was devoted to technical training. $50-55 \%$ of the general time was devoted to group preparation.

The competitive period included an interval of time from the first to the last calendar competitions of year.

Psychophysical preparation included application of special sets of exercises which integrally influence on motor preparation and on athletes' consciousness (development of their figurative thinking, ability to transfer emotions, to express completely the program theme).

Theoretical preparation during this period was directed to study of competitions' features. Programs and results of world-class athletes were analyzed. Pieces of music for programs were selected.

The transition period began after the end of competitions. It proceeded before renewal of classes in a new summer cycle. Tasks of a transition period were the follows: full active rest; keep of a certain level of fitness. Active rest is organized due to change of sport activity type. Total amount of physical activities intensity decreased in a transition period.

In experimental group results of athletes' testing show essential increase of the majority of studied indicators of special physical preparation (tab. 2).

\section{Discussion.}

In sport aerobics athletes unite in groups for performances in various competitive categories. Optimum selection of team list influences on success of performances at competitions. It should be noted that questions of individual distinctions of athletes are practically not study. Such distinctions are shown in individual characteristics of athletes (psychological, physiological, psychophysiological). This question is important for ensuring success of performances at competitions. Such approach is confirmed by other researches of athletes' success [43]. Therefore the offered methods of leading factors definition include a wide complex of analyzed indicators. Our results represent new approach to a problem of individual preparation. Individual approach to training is used also in other types of physical exercises [44]. It is confirmation of relevance of our results. Besides, it was offered for the first time application of the cluster analysis for athletes division into groups. It allows to perform more successfully in various competitive categories of sport aerobics.

Training of athletes is based on system approach. It is extension of the data presented in other researches [40] in different kinds of sport $[45,46]$. However such data was obtained for the first time in sport aerobics.

The individual approach holds a special place in the system of athletes' preparation. It is especially important at a complete set of teams in sports aerobics. It should be noted that in physical culture and sport there are two main approaches. The first approach presupposes existence of

Table 2. Indicators of athletes' physical preparation of control $(n=22)$ and experimental $(n=24)$ groups before and after pedagogical experiment

\begin{tabular}{lllllll}
\hline \multicolumn{1}{c}{ Indicators } & $\begin{array}{l}\text { Experimental group } \\
\text { Before experiment } \\
(\bar{X} \pm S)\end{array}$ & $\begin{array}{l}\text { After experiment } \\
(\bar{X} \pm S)\end{array}$ & $\mathbf{t}$ & $\begin{array}{l}\text { Control group } \\
\text { Before } \\
\text { experiment }\end{array}$ & $\begin{array}{l}\text { After } \\
\text { experiment }\end{array}$ & t \\
\hline Force of right hand, $\mathrm{kg}$ & $26,87 \pm 2,41$ & $31,07 \pm 2,30^{* * *}$ & 6,18 & $27,80 \pm 2,43$ & $28,67 \pm 2,45$ & 1,18 \\
Force of left hand, $\mathrm{kg}$ & $23,60 \pm 2,43$ & $29,80 \pm 2,42^{* * *}$ & 8,86 & $21,53 \pm 2,40$ & $22,47 \pm 2,44$ & 1,29 \\
Angle in hanging, sec & $7,73 \pm 1,15$ & $12,26 \pm 3,01^{* * *}$ & 6,89 & $7,67 \pm 1,70$ & $7,78 \pm 2,82$ & 0,16 \\
Long jump, cm & $172,0 \pm 15,6$ & $181,5 \pm 14,2^{*}$ & 2,21 & $171,6 \pm 14,8$ & $179,0 \pm 15,0$ & 1,65 \\
30 m run, sec & $5,07 \pm 0,29$ & $4,81 \pm 0,28^{* *}$ & 3,16 & $5,08 \pm 0,10$ & $5,03 \pm 0,09 *$ & 1,74 \\
Forward bend, cm & $12,73 \pm 2,73$ & $17,20 \pm 2,85^{* * *}$ & 5,55 & $12,60 \pm 2,75$ & $13,07 \pm 2,77$ & 0,56 \\
Forward split, cm & $4,02 \pm 1,55$ & $1,21 \pm 0,20^{* * *}$ & 8,81 & $4,06 \pm 0,44$ & $4,00 \pm 0,41$ & 0,47 \\
«Flamingo» test, sec & $8,93 \pm 1,48$ & $14,41 \pm 0,9^{* * *}$ & 15,50 & $8,66 \pm 1,42$ & $10,92 \pm 1,20^{* * *}$ & 5,70 \\
Combination, points & $7,33 \pm 1,35$ & $9,46 \pm 1,48^{* * *}$ & 5,21 & $7,35 \pm 1,23$ & $7,98 \pm 1,24$ & 1,69 \\
\hline
\end{tabular}

Note: ${ }^{*}$ - deviations are reliable at $\mathrm{p} \mathrm{p}<0,05 ;{ }^{* *}$ - deviations are reliable at $\mathrm{p}<0,01 ;{ }^{* * *}$ - deviations are reliable at $p<0,001$. 
rigid system of preparation. Such system allows athlete to receive the individual style. The efficiency of such approach is rather presented in researches devoted to single combats [47]. Such approach isn't recommended for sport aerobics.

The second approach is peculiar to sport aerobics. It presupposes definition of athlete's tendencies to a certain motor style. Possibilities of research the individual motor style are shown in other works [48]. Such approach allowed to increase efficiency of athletes' preparation. We agree with opinion of other authors concerning necessity of choice the adequate tests and forms of pedagogical control [49]; optimization of physical activities [50].

These two approaches are closer to each other: using American approach athletes training differently and keep own identity; using European approach athletes training according one system and also keep own identity. It is in evidence in individual and in team performances.

Our work contains new data concerning teams' formation for performances in various competitive categories; integrated preparation considering psychophysiological opportunities of athletes. It provides the strategy of athletes' training.

\section{Conclusions}

The general principles of training programs preparation are developed. Programs include basic and variable components. The basic component of programs represents the standardized structure of means and methods selection of athletes' preparation. Such structure is identical to all formed groups of athletes. The variable component of preparation programs contains special means and methods. They are different on character and volume for the athletes of every group. One of the main parts of a variable component is the psychophysical training. It is based on performance of special sets of exercises in combination with mental figurative representations of motor nature.

\section{Conflict of interests}

The authors declare that there is no conflict of interests.

\section{References}

1. Andersyan KB. Modeling a year cycle of training in sports aerobics. Teoriya i praktika fizicheskoy kulturyi 1993; 5-6: 18-20. (in Russian)

2. Li Y. Effects of Aerobics Dance on Physiological Function of Female College Students. Proceedings of 2014 3rd International Conference on Physical Education and Society Management. Lecture Notes in Management Science. 2014;22: 61-65.

3. Ao H. Educational Reform of Aerobics Course in Sports Colleges and Universities. Proceedings of the 2014 International Conference on Global Economy, Finance and Humanities Research. Advances in Intelligent Systems Research. 2014;112:1-2.

4. Chen J. Exploration of Aerobics Teaching Reform. Fourth International Conference on Education and Sports Education. Lecture Notes in Management Science. 2013;11:312-315.

5. Li L, Fan SQ. Study of the Feasibility of Offering the Course of Hip Hop Dancing in Institute of Physical Education of Huanghe Science and Technology College. 2nd International Conference on Social Science and Health. Advances in Education Research, 2014; 56:92-99.

6. Lina S, Hua T. Study on Different Sports Courses Influence on College Students. Procedia Engineering. 2011;23:1-5.

7. Zhou MH, Cheng N. A Study on the Necessity of Promoting "National Primary and Secondary School Students Martial Arts Aerobics” in Primary and Secondary School. Proceedings of the 2016 International Conference on Education, Management Science and Economics. Advances in Social Science Education and Humanities Research, 2016; 65:340-343.

8. Kalina RM, Jagiello W, Chodala A. The result of "testing fights in a vertical posture" as a criterion of talent for combat sports and self-defence - secondary validation (part II: the accuracy). Archives of Budo Science of Martial Arts and Extreme Sports. 2016;12:18.

9. Li A. An Analysis of Physiological and Psychological Rehabilitation from Injuries of Sport Aerobics Athletes. 4th International Conference on Education and Education Management. Advances in Education Research, 2014;
63:206-209.

10.Li L. Research on Aerobics Movement Choreography based on Embedded Network Technology. Mechatronics Engineering, Computing and Information Technology. Applied Mechanics and Materials. 2014;1:5685-5689.

11.Bigliassi M, Silva VB, Karageorghis CI, Bird JM, Santos PC, Altimari LR. Brain mechanisms that underlie the effects of motivational audiovisual stimuli on psychophysiological responses during exercise. Physiology \& Behavior. 2016;158:128-136. doi:10.1016/j.physbeh.2016.03.001

12.Buhmann J, Desmet F, Moens B, Van Dyck E, Leman M. Spontaneous Velocity Effect of Musical Expression on SelfPaced Walking. Plos One. 2016;11(5). doi:10.1371/journal. pone. 0154414

13. Chow EC, Etnier JL. Effects of music and video on perceived exertion during high-intensity exercise. Journal of Sport and Health Science. 2017;6(1):81-88. doi:10.1016/j. jshs.2015.12.007

14.Clark IN, Baker FA, Taylor NF. The modulating effects of music listening on health- related exercise and physical activity in adults: a systematic review and narrative synthesis. Nordic Journal of Music Therapy. 2016;25(1):76-104. doi:10 .1080/08098131.2015.1008558

15.Maes PJ, Buhmann J, Leman M. 3Mo: A Model for MusicBased Biofeedback. Frontiers in Neuroscience. 2016;10. doi:10.3389/fnins.2016.00548

16.Smirmaul BP. Effect of pre-task music on sports or exercise performance. Journal of Sports Medicine and Physical Fitness. 2017;57(7-8):976-984. doi:10.23736/s00224707.16.06411-2

17.Wu T. The experimental research on Dynamic hierarchical mode. Material Science, Civil Engineering and Architecture Science, Mechanical Engineering and Manufacturing Technology Ii. Applied Mechanics and Materials, 2014;2:2541-2544.

18.Kozina ZL, Iermakov SS, Kadutskaya LA, Sobyanin FI, Krzeminski M, Sobko IN, Ryepko OA. Comparative characteristic of correlation between pulse subjective indicators of girl students' and school girls' reaction to physical load. Physical Education of Students. 2016;20(4):24- 
34. doi:10.15561/20755279.2016.0403

19.Cotter JA, Garver MJ, Dinyer TK, Fairman CM, Focht BC. Ratings of perceived exertion during acute resistance exercise performed at imposed and self-selected loads in recreationally trained women. Journal of Strength and Conditioning Research. 2017;31(8):2313-2318.

20.Saw AE, Main LC, Gastin PB. Monitoring the athlete training response: subjective self-reported measures trump commonly used objective measures: a systematic review. British Journal of Sports Medicine. 2016;50(5):281-+. doi:10.1136/bjsports-2015-094758

21.Osipov AY, Kudryavtsev MD, Kramida IE, Iermakov SS, Kuzmin VA, Sidorov LK. Modern methodic of power cardio training in students' physical education. Physical Education of Students. 2016;20(6):34-39. doi:10.15561/20755279.2016.0604

22.Zinner C, Sperlich B, Born DP, Michels G. Effects of combined high intensity arm and leg training on performance and cardio-respiratory measures. Journal of Sports Medicine and Physical Fitness. 2017;57(7-8):969-975. doi:10.23736/ s0022-4707.16.06539-7

23.Kopeikina EN, Drogomeretsky VV, Kondakov VL, Kovaleva MV, Iermakov SS. Modification of Harvard step-test for assessment of students' with health problems functional potentials. Physical Education of Students. 2016;20(4):4450. doi:10.15561/20755279.2016.0405

24. Tong TK, McConnell AK, Lin H, Nie JL, Zhang HF, Wang JY. "Functional" inspiratory and core muscle training enhances running performance and economy. Journal of Strength and Conditioning Research. 2016;30(10):2942-2951.

25. Vorup J, Pedersen MT, Melcher PS, Dreier R, Bangsbo J. Effect of floorball training on blood lipids, body composition, muscle strength, and functional capacity of elderly men. Scandinavian Journal of Medicine \& Science in Sports. 2017;27(11):1489-1499. doi:10.1111/sms.12739

26.Kozina ZL, Iermakov SS, Kuzmin VA, Kudryavtsev MD, Galimov GJ. Change of Cortisol and Insulin Content in Blood under Influence of Special Workability Recreation System for Students with High Motor Functioning Level. Research Journal of Pharmaceutical Biological and Chemical Sciences. 2016;7(2):1068-1077.

27.Gmiat A, Mieszkowski J, Prusik K, Prusik K, Kortas J, Kochanowicz A, et al. Changes in pro-inflammatory markers and leucine concentrations in response to Nordic Walking training combined with vitamin D supplementation in elderly women. Biogerontology 2017:1-14. doi:10.1007/s10522017-9694-8

28.Kortas J, Kuchta A, Prusik K, Prusik K, Ziemann E, Labudda $\mathrm{S}$, et al. Nordic walking training attenuation of oxidative stress in association with a drop in body iron stores in elderly women. Biogerontology 2017: 1-8. doi:10.1007/s10522-0179681-0

29.Ziolkowski A, Zubrzycki I, Blachnio A, Drobnik P, Zaranska $\mathrm{B}$, Moska W. Influence of sport activity on satisfaction with life and sense of coherence among physically disabled people. Baltic Journal of Health and Physical Activity. 2016;8(4):109-16.

30.Zarebska A, Jastrzebski Z, Moska W, Leonska-Duniec A, Kaczmarczyk M, Sawczuk M, et al. The AGT Gene M235T Polymorphism and Response of Power-Related Variables to Aerobic Training. Journal of Sports Science and Medicine. 2016;15(4):616-24.

31.Kriventsova I, Pashkevych S, Iermakov S, Bartík P, Michal J, Nosko M, Yermakova T. Fitness - aerobic training of 15 - 17 years' age girl students, who have significant risk of deviations in backbone functional state. Journal of Human
Sport and Exercise, 2017;12(4), 1289-1297. doi:10.14198/ jhse.2017.124.15

32.Shepelenko TV, Kozina ZhL, Cieslicka M, Prusik K, Muszkieta R, Sobko IN, Ryepko OA, Bazilyuk TA, Polishchuk SB, Osiptsov AV, Kostiukevych VM. Factorial structure of aerobics athletes' fitness. Pedagogics, psychology, medicalbiological problems of physical training and sports, 2017; 21(6): 291-300. doi:10.15561/18189172.2017.0606

33.Clemente FM, Silva F, Martins FML, Kalamaras D, Mendes RS. Performance Analysis Tool for network analysis on team sports: A case study of FIFA Soccer World Cup 2014. Proceedings of the Institution of Mechanical Engineers Part P. Journal of Sports Engineering and Technology. 2016;230(3):158-170. doi:10.1177/1754337115597335

34.Denardi RA, Clavijo FAR, de Oliveira TAC, Travassos B, Tani G, Correa UC. The volleyball setter's decision-making on attacking. International Journal of Performance Analysis in Sport. 2017;17(4):442-457. doi:10.1080/24748668.2017. 1350450

35.Fontana FY, Colosio AL, Da Lozzo G, Pogliaghi S. Player's success prediction in rugby union: From youth performance to senior level placing. Journal of Science and Medicine in Sport. 2017;20(4):409-414. doi:10.1016/j.jsams.2016.08.017

36.Gelbart M, Ziv-Baran T, Williams CA, Yarom Y, DubnovRaz G. Prediction of Maximal Heart Rate in Children and Adolescents. Clinical Journal of Sport Medicine. 2017;27(2):139-144. doi:10.1097/jsm.0000000000000315

37.Hegedus EJ, McDonough S, Bleakley C, Baxter GD, DePew JT, Bradbury I, et al. Physical performance tests predict injury in National Collegiate Athletic Association athletes: a three-season prospective cohort study. British Journal of Sports Medicine. 2016;50(21):1333-+. doi:10.1136/ bjsports-2015-094885

38.Iguchi J, Watanabe Y, Kimura M, Fujisawa Y, Hojo T, Yuasa Y, et al. Risk factors for injury among japanese collegiate players of american football based on performance test results. Journal of Strength and Conditioning Research. 2016;30(12):34053411. doi:10.1519/jsc.0000000000001429

39.Ishimaru D, Matsumoto K, Ogawa H, Sumi H, Sumi Y, Akiyama H. Characteristics and Risk Factors of Spinal Fractures in Recreational Snowboarders Attending an Emergency Department in Japan. Clinical Journal of Sport Medicine. 2016;26(5):405-410. doi:10.1097/ jsm.0000000000000267

40.Zhanneta K, Irina S, Tatyana B, Olena R, Olena L, Anna I. The applying of the concept of individualization in sport. Journal of Physical Education and Sport. 2015;15(2):172177. doi:10.7752/jpes.2015.02027

41.Sobko I. An innovative method of managing the training process of qualified basketball players with hearing impairment. Journal of Physical Education and Sport, 2015;15(4):640-645: doi:10.7752/jpes.2015.04097

42.Anokhin PK, Shuleikina KV. System organization of alimentary behavior in the newborn and the developing cat. Developmental Psychology, 1977;10(5): 385-419.

43.Podrigalo LV, Iermakov SS, Jagiello W. Special indices of body composition as a criterion of somatic development of martial arts practitioners. Archives of Budo Science of Martial Arts and Extreme Sports. 2017;13:5-12.

44.Druz VA, Iermakov SS, Nosko MO, Shesterova LY, Novitskaya NA. The problems of students' physical training individualization. Pedagogics Psychology MedicalBiological Problems of Physical Training and Sports. 2017;21(2):51-59. doi:10.15561/18189172.2017.0201

45.Osipov AY, Kudryavtsev MD, Iermakov SS, Jagiello W. Topics of doctoral and postdoctoral dissertations devoted to 
judo in period 2000-2016-the overall analysis of works of Russian experts. Archives of Budo. 2017;13:1-10.

46.Kriventsova I, Iermakov S, Bartik P, Nosko M, Cynarski WJ. Optimization of student-fencers' tactical training. Ido Movement for Culture-Journal of Martial Arts Anthropology. 2017;17(3):21-30. doi:10.14589/ido.17.3.3

47.Doroshenko EY, Svatyev AV, Iermakov SS, Jagiełło W. The use of cardio training facilities in training 7-9 year old judo athletes. Archives of Budo Science of Martial Arts and Extreme Sports. 2017;13.
48.Osipov AY, Kudryavtsev MD, Iermakov SS, Jagiello W. Criteria for effective sports selection in judo schools - on example of sportsmanship's progress of young judo athletes in Russian Federation. Archives of Budo. 2017;13:179-186.

49.Khudolii OM, Ivashchenko OV, Iermakov SS, Rumba OG. Computer simulation of junior gymnasts' training process. Science of Gymnastics Journal. 2016;8(3):215-228.

50.Jagiełło M, Iermakov SS, Nowiński M. Differentiation of the somatic composition of students physical education specialising in various sports. Archives of Budo Science of Martial Arts and Extreme Sports. 2017;13.

\section{Information about the authors:}

Kozina Zh.L. (Corresponding author); http://orcid.org/0000-0001-5588-4825; Zhanneta.kozina@gmail.com; H.S. Skovoroda Kharkiv National Pedagogical University; Alchevskyh str. 29, Kharkov, 61002, Ukraine.

Shepelenko T.V.; http://orcid.org/0000-0002-6401-2364; shepelenko_tatyana@ukr.net; Ukrainian State University of Railway Transport; Feuerbach square 7, Kharkov, 61050, Ukraine.

Cieślicka Mirosława; http://orcid.org/0000-0002-0407-2592; cudaki@op.pl; Kazimierz Wielki University in Bydgoszcz; Chodkiewicza str. 30, 85-064 Bydgoszcz, Poland.

Prusik Krzysztof; http://orcid.org/0000-0001-7534-675X; prusik6471@gmail.com; Department of Tourism and Recreation, Gdansk University of Physical Education and Sport; Kazimierza Górskiego 1, 80-336 Gdańsk, Poland.

Muszkieta Radosław; http://orcid.org/0000-0001-6057-1583; radek@muszkieta.com; Nicolaus Copernicus University in Torun; Jurija Gagarina 11, 87-100 Toruń, Poland.

Osiptsov A.V.; http://orcid.org/0000-0002-1640-2632; osipcov_andrey@mail.ru; Mariupol State University; Budivelnykiv Ave., 129a, Mariupol, 87500, Ukraine.

Kostiukevych V.M.; http://orcid.org/0000-0002-6215-764X; v.m.kost@mail.ru; Mykhailo Kotsyubynskyi Vinnitsa State Pedagogical University; Ostrozky str. 32, Vinnitsa21100, Ukraine.

Bazilyuk T.A.; http://orcid.org/0000-0002-6244-6302; baziluk@rambler.ru; Kiev National University of Technology and Design; st. Nemirovich-Danchenko, 2, Kiev, 01000, Ukraine.

Sobko I.N.; http://orcid.org/0000-0002-4920-9775; sobko.kh@mail.ru; Kharkov National Economic University; Lenina boulevard 9a, 61001, Kharkov, Ukraine.

Ryepko O.A.; http://orcid.org/0000-0001-6879-6015; chigiki.ua@mail.ru; H.S. Skovoroda Kharkiv National Pedagogical University; Altshevskih str. 29, Kharkov, 61002, Ukraine.

Polishchuk S.B.; http://orcid.org/0000-0001-8275-4567; staspolischuk@mail.ru; H.S. Skovoroda Kharkiv National Pedagogical University; Altshevskih str. 29, Kharkov, 61002, Ukraine.

Ilnickaya A.S.; http://orcid.org/0000-0001-5835-8847; anita487@mail.ru; H.S. Skovoroda Kharkiv National Pedagogical University; Altshevskih str. 29, Kharkov, 61002, Ukraine.

Cite this article as: Shepelenko TV, Kozina ZhL, Cieślicka M, Prusik K, Muszkieta R, Osiptsov AV, Kostiukevych VM, Bazilyuk TA, Sobko IN, Ryepko OA, Polishchuk SB, Ilnickaya AS. Structure of a year cycle of athletes training in aerobics (woman) with various psychophysiological and functional features. Pedagogics, psychology, medical-biological problems of physical training and sports, 2018;22(1):35-43. doi:10.15561/18189172.2018.0105

The electronic version of this article is the complete one and can be found online at: http://www.sportpedagogy.org.ua/index.php/PPS/issue/archive

This is an Open Access article distributed under the terms of the Creative Commons Attribution License, which permits unrestricted use, distribution, and reproduction in any medium, provided the original work is properly cited (http://creativecommons.org/licenses/by/4.0/deed.en).

Received: 05.09.2017

Accepted: 06.10.2017; Published: 26.02.2018 